\title{
ArcheoSciences
}

Revue d'archéométrie

33 (suppl.) | 2009

Mémoire du sol, espace des hommes

\section{GPR prospection at Borgholm castle, Öland, Sweden}

Immo Trinks, Pär Karlsson, Magnus Stibéus, Clas Ternström and Alois Hinterleitner

\section{(2) OpenEdition}

\section{Journals}

Electronic version

URL: https://journals.openedition.org/archeosciences/1508

DOI: $10.4000 /$ archeosciences. 1508

ISBN: 978-2-7535-1599-4

ISSN: $2104-3728$

Publisher

Presses universitaires de Rennes

Printed version

Date of publication: 30 October 2009

Number of pages: $159-162$

ISBN: 978-2-7535-0943-6

ISSN: $1960-1360$

Electronic reference

Immo Trinks, Pär Karlsson, Magnus Stibéus, Clas Ternström and Alois Hinterleitner, "GPR prospection at Borgholm castle, Öland, Sweden", ArcheoSciences [Online], 33 (suppl.) | 2009, Online since 30

October 2011, connection on 01 February 2022. URL: http://journals.openedition.org/archeosciences/ 1508 ; DOI: https://doi.org/10.4000/archeosciences. 1508 


\title{
GPR prospection at Borgholm castle, Öland, Sweden
}

\author{
Immo Trinks*, Pär Karlsson*, Magnus Stibéus*, \\ Clas Ternström* and Alois Hinterleitner **
}

Key words: GPR, excavation, Castle, Öland, Sweden.

South of the town of Borgholm on the island of Öland, Borgholm castle is located in a barren landscape on a limestone plateau offering great views over Kalmar Sound. It is a well known historical building in Sweden, reflecting various different building styles. The first castle was built in the 12 th century and contained a circular defense tower. In 1572-1589 it was converted into an impressive Renaissance castle, which was heavily damaged during the Kalmar war of 1611-1613. Several years later Nicodemus Tessin the Elder obtained orders from King Karl X Gustaf to rebuild the castle into a Baroque palace, a work that was never completed. The palace was already partly in ruins when a blaze destroyed the entire building in 1806. After the fire only the thick, naked limestone walls remained. The castle was declared a national monument in 1929. Today it is owned and managed by the Swedish National Property Board (SFV).

During the past three years the archaeological prospection unit of the Swedish National Heritage Board, established in 2005, tested GPR and magnetic prospection methods at selected archaeological sites in Sweden in order to gather reference data. Borgholm castle was considered an interesting site to test the GPR method. Apart from two survey areas outside the castle walls, the rectangular inner courtyard, measuring $54 \times 54 \mathrm{~m}$ and covered now with a lawn, was selected as a test site. The only obstacles present in the yard were six concrete blocks marking the entrance to the museum. In the northern corner of the courtyard stone tiles on the ground mark the location of the 12th century tower which had been excavated archaeologically by Martin Olsson in 1929 (Olsson, 1932). The tower and its $5.5 \mathrm{~m}$ thick walls were presumably demolished in 1652-1653 by the order of Nicodemus Tessin.

The GPR survey was conducted by three people in six hours using a $500 \mathrm{MHz}$ Sensors \& Software Noggin Plus antenna system along $50 \mathrm{~m}$ profiles with a cross-line spacing of $25 \mathrm{~cm}$ and an in-line trace spacing of $5 \mathrm{~cm}$. For positioning, survey lines with $1 \mathrm{~m}$ spacing and an odometer wheel attached to a survey cart were employed.

The measured 203 vertical GPR data sections were merged into a three-dimensional data volume which, after depth conversion assuming a constant signal velocity of $10 \mathrm{~cm} / \mathrm{hs}$, was sliced into $5 \mathrm{~cm}$ thick horizontal GPR depth-slices. The uppermost depth-slices show vehicle tracks cut into the soil as well as the reflections from the stone tiles on the surface (Fig. 1). In the courtyard's western part, at about $40 \mathrm{~cm}$ depth, a rectangular structure appeared which became clearer at a greater depth. The walls of a cellar, $10.5 \times 5.8 \mathrm{~m}$, can be seen as dark anomalies against a relatively homogeneous surrounding (Fig. 2). This cellar is oriented southwest-northeast, slightly diverging from the courtyard orientation, suggesting that it belonged to an older building phase. A $2.5 \mathrm{~m}$ deep and $3 \mathrm{~m}$ wide bulge in the center of the northwestern side of the cellar anomaly disappears with increasing depth, indicating a staircase leading into the basement room.

Already in July 1973 a growth pattern in the grass on top of the cellar had led castellan Jim Rudolfsson to conduct a

* Swedish National Heritage Board, Archaeological Excavation Department. (immo.trinks@raa.se)

** Central Institute for Meteorology and Geodynamics, Vienna. 


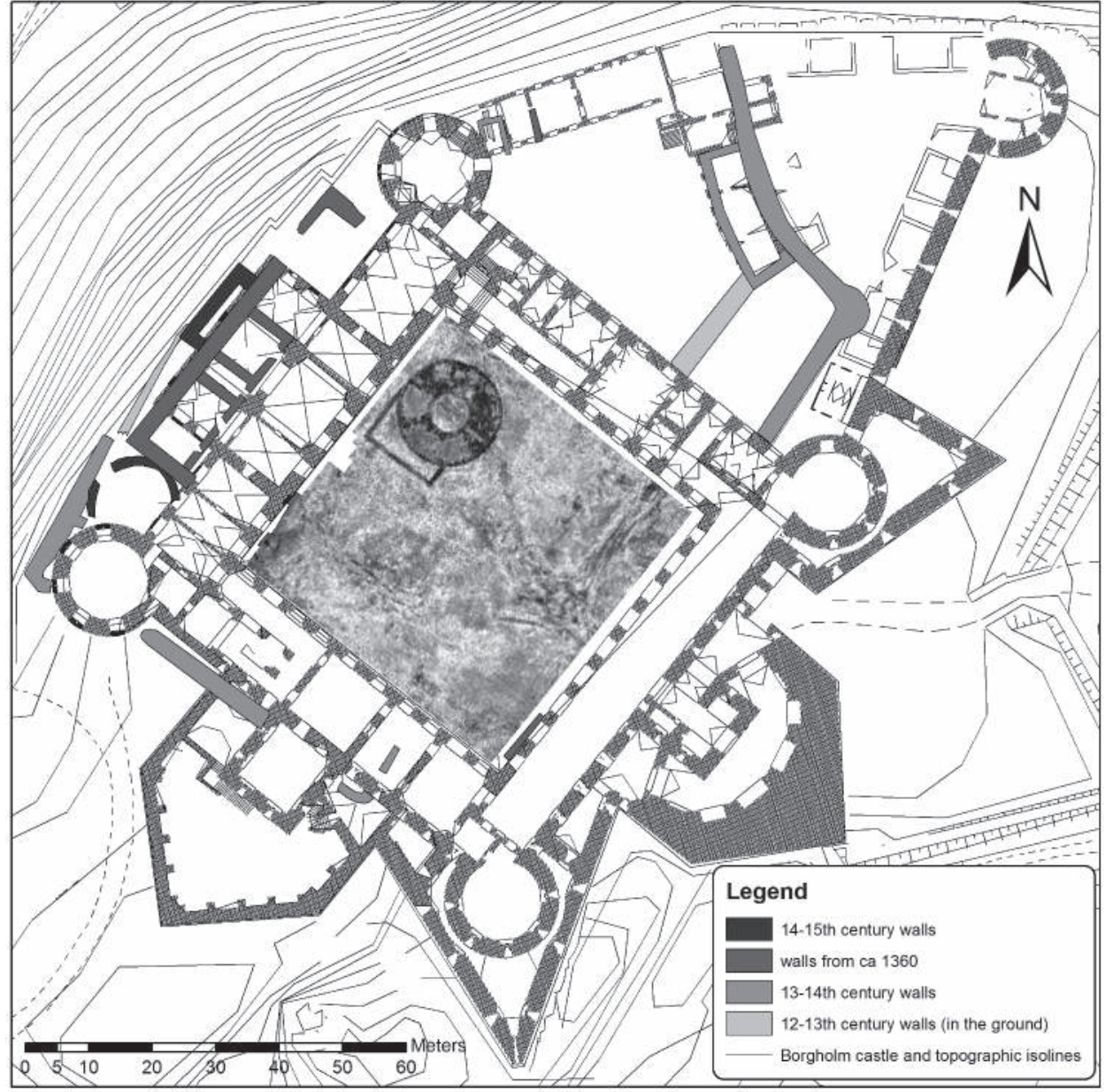

Figure 1: GPR depth-slice from approximately $10-15 \mathrm{~cm}$ depth. Stone tiles and vehicle tracks are clearly visible. trial excavation which resulted in the discovery of a small part of the cellar's northeastern wall.

At even greater depth in the GPR data volume further interesting structures can be seen: a linear structure runs parallel at a distance of 10-20 m to the southeastern side of the courtyard. In the smaller court northeast of the central yard, an older (12th-13th century) defense wall had been excavated earlier, in line with this newly discovered structure. The GPR data shows a continuation of the known older wall inside the main yard (Fig. 3).

In front of the entrance to the main yard, the GPR data indicate the remains of a stone structure, possibly a gate building belonging to the older defense wall.

In the spring of 2008, as part of the "Hemliga rum 2008" ("Secret rooms 2008") project, the Swedish National Property Board opened to the public for one day rooms and buildings that are otherwise inaccessible. on the cellar room mapped by GPR prospection was thus "opened" on Saturday, 24 May 2008. Archaeologists of the Archaeological Excavation
Department of the Swedish National Heritage Board excavated an approximately three square meter measuring area, revealing parts of the walls of the cellar and of the four uppermost steps of the staircase. No dateable finds were made during that dig, but future plans for the excavation of the entire cellar have been discussed. On that day approximately 1500 visitors got the chance to see parts of a room which had been hidden for the past centuries. By the end of the day all the excavated soil and stones were backfilled and carefully cut pieces of turf were put back into place.

\section{References}

Olsson, M., 1932. En grupp runda kastaler från romansk tid på Sveriges östkust. Fornvännen, 5, 1932.

Stibéus, M., 2007. Arkeologi vid Borgholms slott - bebyggelse från järnålder och medeltid. Riksantikvarieämbetet UV Öst, Rapport 2006: 42. 
Figure 2: GPR depth-slice from approximately $70-75 \mathrm{~cm}$ depth. In the western half of the courtyard a rectangular structure with a bulge in its northwestern side can be seen. This structure is interpreted as a cellar with staircase.

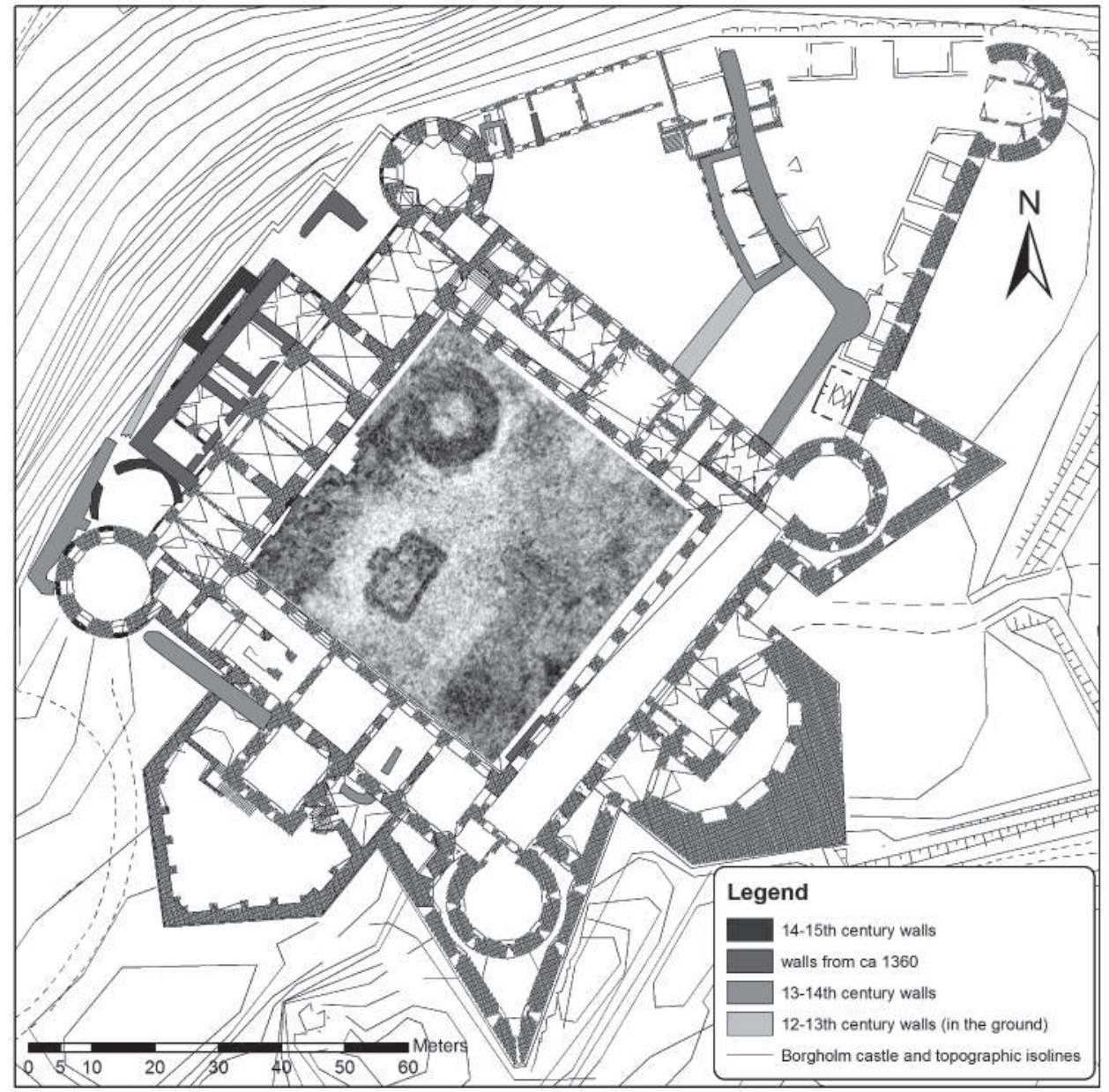




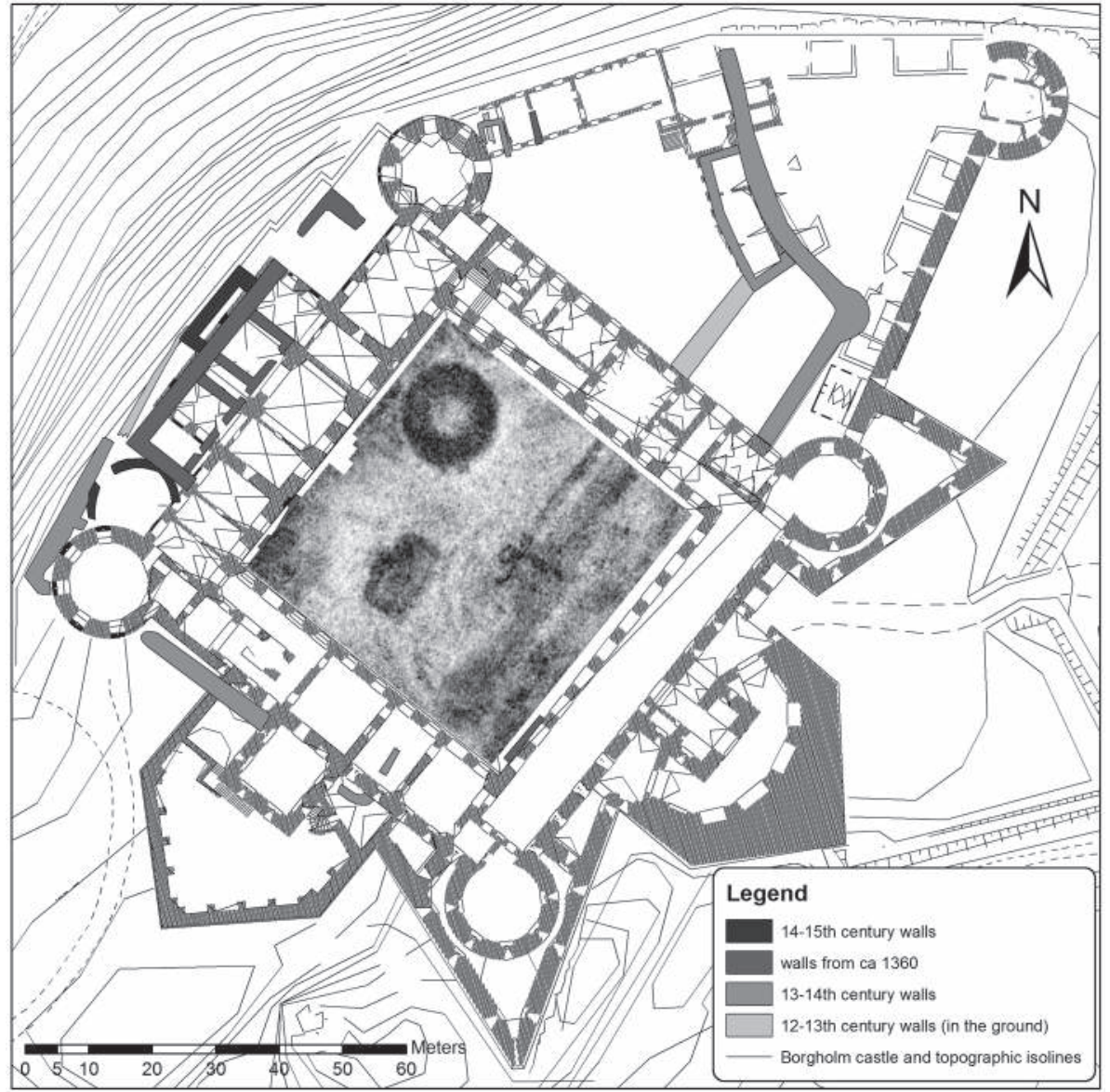

Figure 3: GPR depth-slice from approximately $130-135 \mathrm{~cm}$ depth. The extension of the foundation of the 12 th-13th century walls in the courtyard can be seen, as well as the foundation of a possible gate building. 